\title{
MRPL45 wt Allele
}

National Cancer Institute

\section{Source}

National Cancer Institute. MRPL45 wt Allele. NCI Thesaurus. Code C102973.

Human MRPL45 wild-type allele is located in the vicinity of $17 q 21.2$ and is approximately $26 \mathrm{~kb}$ in length. This allele, which encodes $39 \mathrm{~S}$ ribosomal protein L45, mitochondrial, plays a role in the translation of mitochondrial RNA. 